\title{
Seed removal by different functional mammal groups in a protected and grazed landscape of the Monte, Argentina
}

\author{
Florencia Miguel ${ }^{\star \dagger}$, Mónica I. Cona and Claudia M. Campos \\ Instituto Argentino de Investigaciones de las Zonas Áridas (UNCuyo-Gobierno de Mendoza-CONICET), Mendoza, \\ Argentina
}

(Received 18 July 2016; accepted after revision 20 February 2017; first published online 3 April 2017)

\begin{abstract}
Mammal species contribute in different ways to seed dispersal effectiveness, acting as endozoochorous dispersers, scatter-hoarders and seed predators. Seed removal by these functional mammal groups could be affected by anthropogenic drivers, such as grazing management, a common practice in drylands. We evaluated removal of seeds from a native tree species (Prosopis flexuosa) by terrestrial wildlife mammals with different functional roles, on grazed and ungrazed sites and at different times during the fruiting period of Prosopis. We offered Prosopis fruits, each containing 15 seeds, to animals and used camera traps to identify the species removing them. We obtained the number of seeds removed ( 1 fruit removed $=15$ seeds removed) by each animal species and each functional group. Native and domestic mammals removed $65.4 \%$ of the total seeds offered; $69.5 \%$ of offered seeds were removed from the grazed area and 61\% from the ungrazed site. Considering removal times, $64.25 \%$ of offered seeds were removed during the beginning of the fruiting period of Prosopis and $67 \%$ towards the end of this period. Small mammals acting either as seed predators (Graomys griseoflavus and Akodon dolores) or scatterhoarders (Microcavia australis) were the functional mammal groups removing the highest amount of seeds. Seed predators removed more seeds from the ungrazed site, whereas the scatter-hoarder did so at the grazed site. In the ungrazed area, it would be important to ensure habitat heterogeneity in order to improve seed removal by functional groups that disperse seeds, such as endozoochorous dispersers and scatter-hoarders.
\end{abstract}

Keywords: drylands, grazing, mesquite woodland, scatterhoarders, seed predators

\footnotetext{
* Correspondence

Email: fmiguel@mendoza-conicet.gob.ar

${ }^{+}$Current address: Instituto Argentino de Investigaciones de las Zonas Áridas (IADIZA-CONICET Mendoza), Av. Ruiz Leal s/n Parque General San Martin (5500), Mendoza, Argentina.
}

\section{Introduction}

In drylands, anthropogenic disturbances such as logging, fire, agricultural expansion, and livestock grazing practices can result in loss of habitat and connectivity, with consequent biodiversity losses (Jones, 2000; Asner et al., 2003; Millennium Ecosystem Assessment, 2005; Reynolds et al., 2007), and reduction of animal functional diversity (Chillo and Ojeda, 2012; Periago et al., 2014). In Argentina's drylands, where grazing by domestic animals is the main land use, most studies have focused on the effect of this disturbance on animal populations (e.g. species decrease in abundance at grazed sites) and its impact at the community level (i.e. habitat modifications, such as an increase in bare ground cover, and their impacts on different species' populations) (Tabeni and Ojeda, 2003, 2005; Corbalán, 2006; Tabeni et al., 2007; Rodríguez, 2009). However, little is known about the effects of grazing on biological interactions, such as seed dispersal by animals.

Seed dispersal is crucial for plant populations because it allows new individuals to move away from their mother plant (escape hypothesis; Connell, 1971; Janzen, 1971), explore new areas (colonization hypothesis; Howe and Smallwood, 1982; Nathan, 2006) and regenerate the population (Forget et al., 2001; Jordano et al., 2011). Animal species can contribute differently to the overall effectiveness of seed dispersal a plant receives from its assemblage of dispersal agents (Schupp et al., 2010), among them mammals. Some are endozoochorous dispersers, considered efficient primary seed dispersers that ingest the whole fruit and then defecate or regurgitate the seeds (Janzen, 1983; Jordano, 2000; Forget and Cuijpers, 2008; Vander Wall and Beck, 2012). Other mammal species, mainly rodents, are scatter-hoarders who store seeds in a large number of small caches in the ground for future consumption (Vander Wall and Beck, 2012); and as they eat some seeds but not all of them, they become potential seed dispersers (Vander Wall, 1990, 2002; Forget et al., 2002). In contrast, some hoarding species are mainly seed predators, because they store food in underground caches, generally in unfavourable 
conditions for seed germination and seedling establishment (larder-hoarders; Longland et al., 2001; Vander Wall and Beck, 2012).

In this context, we conducted a study in a protected area (Ñacunán Reserve) surrounded by cattle range areas dominated by Prosopis flexuosa ('algarrobo dulce') woodland in a dryland biome of Argentina. Mammals removing $P$. flexuosa fruits provide different effectiveness to this tree species (Campos and Ojeda, 1997; Campos et al., 2007, 2008; Campos and Velez, 2015). Particularly wildlife species, some are opportunistic frugivores that disperse seeds through endozoochory (e.g. Lycalopex griseus, Dolichotis patagonum; Campos and Ojeda, 1997; Campos et al., 2008; Campos and Velez, 2015), whereas small rodents behave as scatter-hoarders (Microcavia australis, Eligmodontia typus; Giannoni et al., 2001, 2013; Campos and Velez, 2015; Campos et al., 2017) or seed predators through larder-hoarding (Graomys griseoflavus, Akodon dolores; Giannoni et al., 2013).

We focused on studying the effects of cattle grazing activity on $P$. flexuosa seed removal by terrestrial wildlife mammals at two times of the fruiting period. We had the following questions: (1) does grazing affect total seed removal by mammals?; (2) is there any temporal difference in total seed removal during different times of the fruiting period of Prosopis?; and (3) are there any differences in seed removal by different functional mammal groups between the grazed and ungrazed sites during the beginning and by the end of the fruiting period? If the ungrazed site is functioning as a conservation site, we expected a higher total seed removal in ungrazed than in grazed woodland, because undisturbed woodland provides mammals with more food and refuge (Tabeni and Ojeda, 2005; Corbalán, 2006). Because two different time periods were considered, we expected a high total seed removal at the end of the fruiting period, after peak fruit fall, when removal and consumption of fallen fruits and seeds are usually more pronounced (Janzen, 1974; López de Casenave et al., 1998). Finally, we expected that seed removal by the functional mammal groups in both grazed and ungrazed woodlands would be different at different times of the fruiting period due to their natural population fluctuations and habitat preferences (Corbalán and Ojeda, 2004; Tabeni and Ojeda, 2005). In the study area, bare ground cover is higher at the grazed site than in the protected woodland (Tabeni and Ojeda, 2005) and, while some native mammals that disperse Prosopis seeds, such as $M$. australis and $D$. patagonum, are associated with open habitats in the cattle-grazed woodland (Tabeni and Ojeda, 2003; Rodríguez, 2009), and L. griseus prefers open shrubby areas (Jiménez et al., 2008), other species (G. griseoflavus and A. dolores) are more abundant in areas with dense plant cover such as the protected woodland (Tabeni and Ojeda, 2003, 2005; Corbalán, 2006).

\section{Materials and methods}

\section{Study site}

This study was conducted in the Man and Biosphere Ñacuñán Reserve $\left(34^{\circ} 02^{\prime} \mathrm{S}, \quad 67^{\circ} 58^{\prime} \mathrm{W}, 12,800\right.$ ha; Mendoza Province, Argentina) and in an adjoining cattle ranching area (both $540 \mathrm{~m}$ elevation); these sites are located in the Monte biogeographic province (central Monte; Cabrera, 1971; Roig et al., 2009). The climate is semi-arid, with cold dry winters $\left(-13\right.$ to $\left.10^{\circ} \mathrm{C}\right)$ and warm rainy summers $\left(20\right.$ to $\left.42^{\circ} \mathrm{C}\right)$. Average annual rainfall is $329.4 \mathrm{~mm}$ (Estrella et al., 2001). Three main types of plant communities occur in the area: mesquite woodland, creosotebush scrubland, and sand dunes (Roig, 1971). The mesquite woodland is the most representative community; it consists of a tree layer of $P$. flexuosa and Geoffroea decorticans (mean canopy height being $7 \mathrm{~m}$ ), a shrub layer with dominance of Larrea divaricata, L. cuneifolia and Condalia microphylla, and a grass layer of Pappophorum spp. Trichloris crinita and Digitaria californica (Roig, 1971).

At the beginning of the nineteenth century, the area of Ñacuñán suffered severe logging of mesquite woodland and cattle overgrazing (Abraham and Prieto, 1999; Rojas et al., 2009). The reserve was established by law in 1961 with the aim of protecting the mesquite woodland (Roig, 1971), and it was fenced in 1972. This reserve offers a unique situation for research because it is the only area in the Monte where grazing by domestic animals is excluded. The adjoining grazed field is under continuous grazing and also presents other related activities (firewood extraction, subsistence hunting, and establishment of watering points, fences, roads and human settlements). Due to environmental constraints in these rangelands, 20 ha/AU (hectares per animal unit) is a commonly used stocking rate (Guevara et al., 2009). Previous studies in the area showed greater abundance of adult $P$. flexuosa trees in ungrazed than in grazed woodlands (62 and 32 trees in 0.4 ha, respectively; Aschero and Vázquez, 2009).

\section{Tree species}

The study tree, $P$. flexuosa (Fabaceae, Mimosoideae), is a key species in its natural distribution range (Álvarez and Villagra, 2009; Álvarez et al., 2011; Campos and Velez, 2015); it provides the human population with services such as shade and valuable goods like wood and food (Ladio and Lozada, 2009).

Prosopis flexuosa blooms in spring (October to December) and fruits start to ripen in summer (February). When the ripe fruits fall, their persistence beneath tree canopies is short because animals remove most of the fruits and seeds within no more than six weeks after they reach the ground (Villagra et al., 2002; 
Table 1. List of mammal species that removed Prosopis seeds and number of cameras by which species was observed at least once at grazed and ungrazed sites and during the beginning and end of the fruiting period

\begin{tabular}{|c|c|c|c|c|c|c|}
\hline \multirow[t]{2}{*}{ Species } & \multirow[t]{2}{*}{ Role } & \multirow[t]{2}{*}{ Number of cameras } & \multicolumn{2}{|l|}{ Grazed site } & \multicolumn{2}{|c|}{ Ungrazed site } \\
\hline & & & Beginning & End & Beginning & End \\
\hline Akodon dolores & SP & 1 & 0 & 0 & 0 & 1 \\
\hline Chaetophractus vellerosus & UNK & 7 & 5 & 0 & 2 & 0 \\
\hline Conepatus chinga & UNK & 1 & 0 & 0 & 1 & 0 \\
\hline Ctenomys mendocinus & UNK & 1 & 0 & 0 & 1 & 0 \\
\hline Dolichotis patagonum & ED & 6 & 4 & 0 & 2 & 0 \\
\hline Graomys griseoflavus & $\mathrm{SP}$ & 64 & 16 & 11 & 21 & 16 \\
\hline Lycalopex griseus & ED & 24 & 11 & 6 & 0 & 7 \\
\hline Microcavia australis & $\mathrm{SH}$ & 52 & 27 & 6 & 16 & 3 \\
\hline Cow & ED & 13 & 10 & 3 & - & - \\
\hline Horse & ED & 3 & 3 & 0 & - & - \\
\hline
\end{tabular}

Functional groups are: SP (seed predator), UNK ('unknown'), ED (endozoochorous disperser) and SH (scatter-hoarder).

Campos et al., 2007). The fruit is an indehiscent pod, with a relatively soft exocarp (Burkart, 1976) and a thick mesocarp that contains the major portion of sugars and proteins (Kingsolver et al., 1977). Seeds are covered by a bony endocarp and a coat that acts as a barrier inhibiting germination (Warrag, 1994). Germination is accelerated by the passage of seeds through the digestive tracts of animals, with some costs to seed viability (Campos and Ojeda, 1997; Campos et al., 2008).

\section{Seed removal experiment}

We randomly chose adult Prosopis trees separated by a minimum distance of $500 \mathrm{~m}$, both in the protected and the grazed area. Below the canopy of each tree, we placed 20 Prosopis fruits containing 15 seeds each $(n=$ 300 total seeds per tree). Over a 48 -h period, we monitored seed removal and the identity of the mammal species removing seeds from beneath each tree using camera traps (Moultrie, M-900i) mounted on trees at a height of $1.80 \mathrm{~m}$. The supply of whole fruits and the short fruit exposure time helped us prevent fruit removal by ants (C.M. Campos, personal observation). The cameras took three consecutive pictures whenever animal movement was detected, with a 30-s delay between shoots. The location of the cameras allowed us not only to identify animal species, but also to count the number of remaining fruits after the animal had left the place (Grünewald et al., 2010). We offered whole Prosopis fruits and, as seeds can be counted, we used the number of seeds removed by species and by functional mammal groups as response variable in the model (see 'Data analysis' section). Those seeds that had been moved by an animal far from the camera trap's field of view were considered removed.

To assess whether seed removal by mammals changed at two different times during the fruiting period of
P. flexuosa, we conducted the experiment at the beginning of the fruiting period when fruits can be found on the ground beneath the trees (March 2015), and by the end of the fruiting period when almost no fruits are available on the ground (May 2015). The production of Prosopis fruit is highly variable between years, depending on environmental factors (Dalmasso and Anconetani, 1993; Álvarez and Villagra, 2009). A period of low fruit production has been observed from 2013 onwards (C.M. Campos, personal observation).

\section{Data analysis}

Because of the small sample size, we did not include in the model those species with an unknown effect on Prosopis seeds ('unknown' group; see Table 1). As our objective was to compare the effect of cattle grazing activity on seed removal by wild mammals, we also excluded from the analysis data on trees from which seeds were removed by domestic animals. After excluding these trees, the final number of camera traps placed on trees at the beginning of the fruiting period was 40 for protected and 47 for grazed sites; and at the end of the fruiting period it was 20 for protected and 17 for grazed sites.

The total number of seeds removed by each species, pooling across individual visits at every tree (response variable), was considered an estimator of the quantity component of seed dispersal effectiveness (Schupp et al., 2010). The variables considered in our model were: site (with two levels: ungrazed and grazed), fruiting time of $P$. flexuosa (with two levels: beginning and end) and functional group [with three levels: seed predator (SP), scatter-hoarder (SH) and endozoochorous disperser (ED)], and interactions between them. The sign of parameters having significant effects 
Table 2. Results of zero-hurdle model of seeds removed per site (grazed and ungrazed), times during the fruiting period of Prosopis (beginning and end), by different functional groups (FG) of terrestrial mammals (SP: seed predator, ED: endozoochorous disperser and $\mathrm{SH}$ : scatter-hoarder) and interactions among variables

\begin{tabular}{|c|c|c|c|c|c|}
\hline Adjusted model & Coefficient & Estimate & SE & $Z$-value & $P$-value \\
\hline \multirow[t]{8}{*}{ FG $\times$ time + FG $\times$ site } & Intercept & 5.46 & 0.16 & 32.19 & $<0.001$ \\
\hline & Grazed site & -0.37 & 0.19 & -1.88 & 0.05 \\
\hline & ED & -0.65 & 0.36 & -1.80 & 0.07 \\
\hline & $\mathrm{SH}$ & -0.69 & 0.34 & -1.97 & 0.04 \\
\hline & SP: end & 0.67 & 0.35 & 1.92 & 0.04 \\
\hline & ED: grazed & 0.69 & 0.37 & 1.88 & 0.05 \\
\hline & SH: grazed & 0.78 & 0.29 & 2.64 & 0.008 \\
\hline & SP: ungrazed & 0.79 & 0.29 & 2.64 & 0.008 \\
\hline
\end{tabular}

SE, standard error. Significant differences at $P<0.05$ are in bold.

was used to interpret the results (McCulloch and Searle, 2001; Bolker et al., 2009).

To assess whether seed removal by mammals differed between sites (question 1), between different times during the fruiting period of Prosopis (question 2 ), and among the functional mammal groups at both sites during each time of the fruiting period (question 3), we fitted a generalized linear model (GLM) with a Poisson error structure (McCullagh and Nelder, 1989). As we detected a higher amount of zeros than expected for a Poisson distribution, we fitted a zero-inflated model. Following the model building and selection guidelines by Zuur et al. (2009), we obtained and compared the AIC (Akaike information criterion; Akaike, 1981) values from zero-inflated and zero-altered (hurdle) models. Both kinds of models were built with a Poisson and a negative binomial distribution to correct overdispersion. The model we finally chose was the zero-altered negative binomial model (Zeileis et al., 2008; Zuur et al., 2009), which was the one with the lowest AIC value. We included a random tree effect in the model in order to account for pseudoreplication among visits of each species to a tree (Zuur et al., 2009).

All statistical analyses and graphs were performed using R 3.3.1 language and environment (R Development Core Team, 2016). We used the hurdle() function from the 'pscl' package for the building of a zero-altered negative binomial model (Zeileis et al., 2008).

\section{Results}

During the 280 camera-trap nights (200 for the beginning and 80 for the end of the fruiting period), $65.4 \%$ $(n=24,315)$ of the total seeds offered $(n=37,200)$ were removed, with mammals being the only seed removers. We recorded ten species removing Prosopis seed, with $G$. griseoflavus, M. australis and L. griseus being the species recorded (at least once) by the highest number of camera traps (Table 1). Results on domestic mammals are provided for information purposes only. Cows and horses removed seeds from 16 Prosopis trees (Table 1); whereas cows removed seeds during the beginning and end of the fruiting period (mean \pm SE number of removed seeds was $26.54 \pm 8.4$ and $21.75 \pm 15.83$, respectively), horses were only recorded during the beginning of the period (13.08 \pm 7.27$)$.

Regarding our first question, $69.5 \%$ of offered seeds were removed from the grazed area and $61 \%$ from the ungrazed site. Pooling across all species, there was no difference between sites in total number of seeds removed $(Z=-1.88 ; \quad P=0.5$ : Table 2). Considering times, $64.25 \%$ of offered seeds were removed during the beginning of the fruiting period and $67 \%$ at the end. There was no statistically significant difference in the number of total seeds removed between times $(Z=-1.91 ; P=0.5$; Table 2).

The number of seeds removed by different functional mammal groups varied within sites and between times during the Prosopis fruiting season (Table 2). The total number of seeds removed by seed predators and by the scatter-hoarder was higher than that removed by endozoochorous dispersers (Tables 2 and 3; Fig. 1). Considering groups with the highest number of Prosopis seed removed (seed predators and scatterhoarder), the model showed site-related differences during the fruiting period of Prosopis. The total number of seeds removed by seed predator species was higher at the end of the period and at the ungrazed site, whereas the total number of seed removed by the scatter-hoarder was higher during the beginning of the fruiting period and at the grazed site (Table 2; Fig. 1).

\section{Discussion}

Regarding our predictions, we expected a higher total seed removal by wild mammals at the ungrazed site 
Table 3. Mean number \pm SE of seeds removed and number of visits of each mammal species, and mean number \pm SE of seeds removed from both sites (grazed and ungrazed) and times (beginning and end) during the fruiting period

\begin{tabular}{|c|c|c|c|c|c|c|c|}
\hline Role & Species & $\begin{array}{l}\text { Total seeds } \\
\text { removed }\end{array}$ & $\begin{array}{l}\text { Total number } \\
\text { of visits }\end{array}$ & Beginning & End & Beginning & End \\
\hline \multirow[t]{2}{*}{ SP } & Graomys griseoflavus & $14.42 \pm 1.84$ & $2.84 \pm 0.39$ & $7.32 \pm 1.77$ & $15.65 \pm 3.8$ & $21 \pm 5$ & $22 \pm 3$ \\
\hline & Akodon dolores & 0.11 & 0.01 & 0 & 0 & 0 & 0.75 \\
\hline $\mathrm{SH}$ & Microcavia australis & $18.08 \pm 2.56$ & $1.61 \pm 0.23$ & $24 \pm 4$ & $10.7 \pm 4.7$ & $20 \pm 5$ & $3.34 \pm 1.9$ \\
\hline \multirow[t]{3}{*}{ UNK } & Chaetophractus vellerosus & $2.41 \pm 1.13$ & $0.06 \pm 0.03$ & $3.38 \pm 1.71$ & 0 & $3.38 \pm 3$ & 0 \\
\hline & Conepatus chinga & 0.32 & 0.01 & 0 & 0 & 1.13 & 0 \\
\hline & Ctenomys mendocinus & 0.32 & 0.01 & 0 & 0 & 1.13 & 0 \\
\hline
\end{tabular}

and at the end of the fruiting period but, contrary to expectations, total seed removal did not differ between grazed and ungrazed sites or between times. However, we did find differences in the number of seeds removed between the functional mammal groups at the different times studied and at both sites.
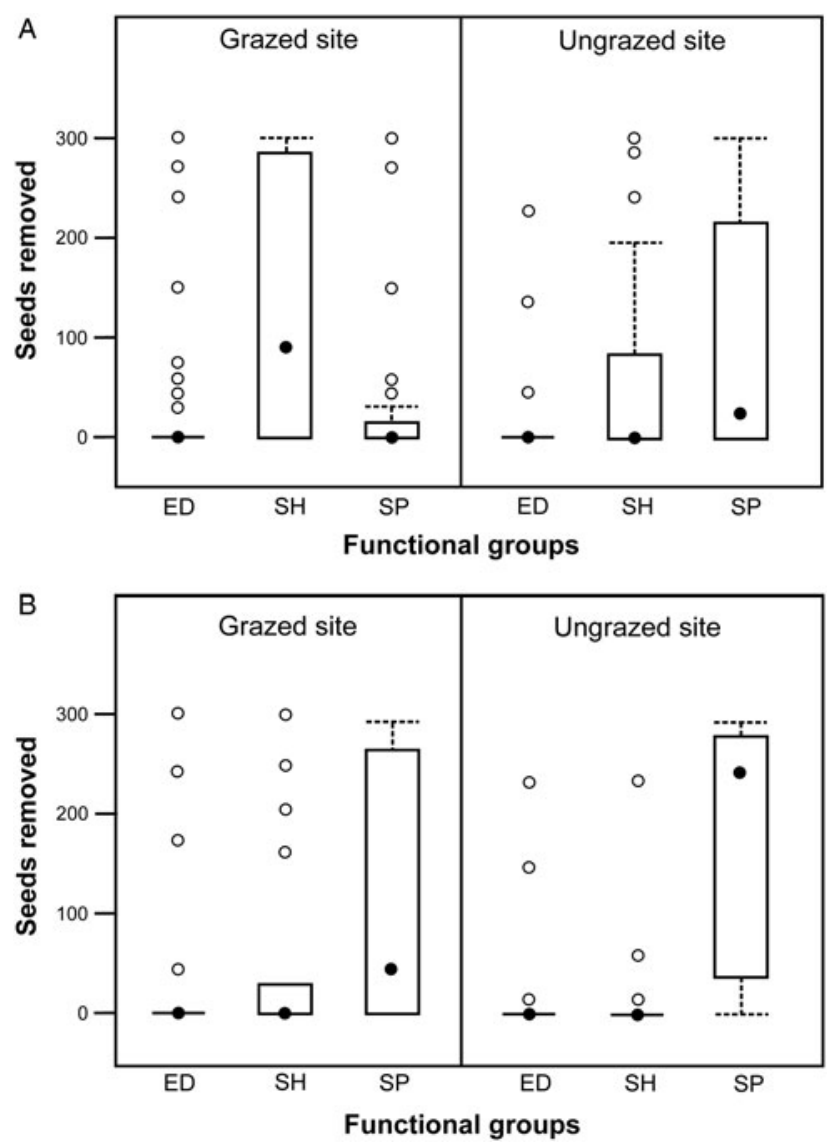

Figure 1. Boxplots of seeds removed per functional group at grazed and ungrazed sites during (A) the beginning and (B) the end of the fruiting period of Prosopis. Functional groups are: ED (endozoochorous disperser), SH (scatter-hoarder) and SP (seed predator).
By using camera traps, we were able to identify wild mammal species removing fruits, quantify the number of visits, and estimate the number of Prosopis seeds removed by each species. As a result, we found that species recorded by the highest number of camera traps (G. griseoflavus, M. australis and L. griseus; Table 1) had the highest number of feeding visits to the trees and also removed the highest amount of seeds (Table 3). Mammals with an 'unknown' contribution to the Prosopis seed dispersal effectiveness were recorded by a lower number of cameras than small and medium-sized mammal species.

The role of small rodents as being responsible for most of the seed removal was previously reported for the Neotropics (e.g. Sánchez-Cordero and MartínezGallardo, 1998; Iob and Vieira, 2008). It is also known that, in drylands around the world, invertebrates and small rodents are the main groups removing seeds and acting as seed predators or seed dispersers (Abramsky, 1983; Linzey and Washok, 2000; Marone et al., 2000; Kelt et al., 2004). Consistent with this general description, results from our study site showed that the main functional mammal groups removing Prosopis seeds were small rodents: two sigmodontine species (seed predators; G. griseoflavus and A. dolores) and one hystricognath species (scatter-hoarder; $M$. australis). Seed removal by medium-sized mammals ( $L$. griseus and D. patagonum; Table 1) was lower than that by small rodents.

Endozoochorous dispersers such as L. griseus and D. patagonum play an active role in dispersing Prosopis seeds (Campos and Ojeda, 1997; Campos et al., 2008); however, none of these species feed exclusively on Prosopis fruits. Also, both species are associated with open habitats (Jiménez et al., 2008; Rodríguez, 2009). Following their habitat requirements, and despite seed removal by this functional group not being statistically different between sites in our study, we found a tendency towards a higher number of trees visited (Table 1) and a higher number of seed removed (Table 2) by these medium-sized 
mammals, particularly by L. griseus, at the grazed site compared with the ungrazed site. The tendency found here indicates a high seed removal activity of these native species at a site where they could be more exposed to risks from human activities, thereby increasing their vulnerability to being hunted (Campos et al., 2001; Tabeni et al., 2013).

During the beginning of the fruiting period of Prosopis, the seed predators (G. griseoflavus and $A$. dolores) at the ungrazed site and the scatter-hoarder (M. australis) at the grazed site were the main functional groups removing seeds. Following our predictions, these results could be related to the habitat requirements of the species. From previous studies we know that grazing by large herbivores causes habitat modifications such as alteration of biomass and vegetation structure with consequent effects on smallsized mammal populations (Jones, 2000; Flowerdew and Ellwood, 2001; Foster et al., 2014). In the central Monte, the main seed predator G. griseoflavus avoids open habitats and is associated with patches of complex vegetation structure on grazed and ungrazed sites (Tabeni et al., 2007). Akodon dolores, which only removed a low number of seeds from the ungrazed site during the end of the fruiting period (Tables 1 and 3), prefers habitats with high plant density inside the ungrazed area (Tabeni and Ojeda, 2005; Corbalán, 2006). In contrast, M. australis, which removed a higher number of seeds from the grazed site, mainly occupies habitats under grazing where vegetation structure allows it to build its colonies under plants with an umbrella-like pattern (Tognelli et al., 1995).

Despite the different number of trees included in our experiment at both fruiting times considered, we found strong tendencies of differential seed removal by mammals on sites under two land management practices. During the end of the period, the seed predator group removed the highest number of seeds. This could be related to the seasonal increase in the population abundance of $G$. griseoflavus occurring in autumn (Ojeda, 1989; Corbalán and Ojeda, 2004). As an advantage from the seed point of view, the time when the peak fall of Prosopis fruits occurs (summer) does not coincide with the time at which the population of their main seed predator is naturally more abundant (autumn).

Our results represent a season of low Prosopis fruit production, considering the high inter-annual variability in crop size of this tree species (Dalmasso and Anconetani, 1993). However, the dynamics of seed removal by mammals found here may vary in a year of higher fruit availability; in that case, mammals may or may not become satiated by large fruit production events (Kelly and Sork, 2002). Also, a previous study in the area found Prosopis seed production to be higher at the protected than grazed sites (Aschero and Vázquez, 2009). Further research in a year of high Prosopis fruit production could explain the seed removal response by mammals in an ecological context of different fruit availability.

In summary, seed predator species removed more seeds compared with other species at the ungrazed site and during the end of the fruiting period, whereas the scatter-hoarding species removed more seeds from the grazed site at the beginning of the period. On the one hand, the nearly 50-year exclusion of large herbivores from the protected area seems to have generated more suitable microhabitats for seed predators and to have caused the expulsion of medium-sized mammals (Tabeni et al., 2013). On the other hand, grazing management could be advantageous for seed removal by a hoarding species and by medium-sized mammals that disperse seeds through endozoochory. Nevertheless, a lower percentage of Prosopis seedling survival was reported for the grazed area compared with the ungrazed site, probably due to intensive cattle trampling (Campos et al., 2011; Aschero et al., 2016). As a first approach to addressing seed removal by mammals using camera traps, and from a plant perspective, a tentative suggestion would be to maintain, in the protected area, a heterogeneity of habitats that ensures that all local wildlife species play their functional roles (Campos et al., 2016), mainly enlarging the habitat associated with seed disperser species.

\section{Acknowledgements}

The authors thank all the staff of Nacuñán Reserve for their cooperation; and the owner and the family in charge for allowing us to work in the cattle ranching area. We also thank three reviewers for comments on an earlier version of the manuscript. Nélida Horak assisted us in drafting the English version.

\section{Financial support}

This work was supported by Consejo Nacional de Investigaciones Científicas y Técnicas (CONICET-PIP 112-201101-00601), Agencia Nacional de Promoción Científica y Tecnológica (PICT-2013-0478) and a graduate fellowship from CONICET to F.M.

\section{Conflicts of interest}

None.

\section{References}

Abraham, E.M. and Prieto, M.R. (1999) Vitivinicultura y desertificación en Mendoza. In García Martínez, B. and 
González Jácome, A. (eds), Estudios sobre Historia del Ambiente en América, pp. 109-135. México: Colegio de México, Instituto Panamericano de Geografía e Historia.

Abramsky, Z. (1983) Experiments on seed predation by rodents and ants in the Israeli desert. Oecologia 57, 328332.

Akaike, H. (1981) Likelihood of a model and information criteria. Journal of Econometrics 16, 3-14.

Álvarez, J.A. and Villagra, P.E. (2009) Prosopis flexuosa DC. (Fabaceae, Mimosoideae). Kurtziana 35, 47-61.

Álvarez, J.A., Villagra, P.E., Villalba, R., Cony, M. and Alberto, M. (2011) Wood productivity of Prosopis flexuosa DC. woodlands in the central Monte: influence of population structure and tree-growth habit. Journal of Arid Environments 75, 7-13.

Aschero, V. and Vázquez, D.P. (2009) Habitat protection, cattle grazing and density-dependent reproduction in a desert tree. Austral Ecology 34, 901-907.

Aschero, V., Morris, W.F., Vázquez, D.P., Alvarez, J.A. and Villagra, P.E. (2016) Demography and population growth rate of the tree Prosopis flexuosa with contrasting grazing regimes in the Central Monte Desert. Forest Ecology and Management 369, 184-190.

Asner, G.P., Borghi, C.E. and Ojeda, R.A. (2003) Desertification in central Argentina: changes in ecosystem carbon and nitrogen from imaging spectroscopy. Ecological Applications 13, 629-648.

Bolker, B.M., Brooks, M., Clark, C., Geange, S., Poulsen, J. and Stevens, M. (2009) Generalized linear mixed models: a practical guide for ecology and evolution. Trends in Ecology and Evolution 24, 127-135.

Burkart, A. (1976) A monograph of the genus Prosopis (Leguminosae Subfam. Mimosoideae). Journal of the Arnold Arboretum 57, 219-249.

Cabrera, A.L. (1971) Fitogeografía de la República Argentina. Boletín de la Sociedad Argentina de Botánica 14, 1-42.

Campos, C.M. and Ojeda, R.A. (1997) Dispersal and germination of Prosopis flexuosa (Fabaceae) seeds by desert mammals in Argentina. Journal of Arid Environments 35, 707-714.

Campos, C.M., Tognelli, M.F. and Ojeda, R.A. (2001) Dolichotis patagonum. Mammalian Species 632, 1-5.

Campos, C.M., Giannoni, S.M., Taraborelli, P. and Borghi, C. (2007) Removal of mesquite seeds by small rodents in the Monte Desert, Argentina. Journal of Arid Environments 69, 228-236.

Campos, C.M., Peco, B., Campos, V.E., Malo, J.E., Giannoni, S.M. and Suárez, F. (2008) Endozoochory by native and exotic herbivores in dry areas: consequences for germination and survival of Prosopis seeds. Seed Science Research 18, 91-100.

Campos, C.M., Campos, V.E., Mongeaud, A., Borghi, C.E., de los Ríos, C. and Giannoni, S.M. (2011) Relationships between Prosopis flexuosa (Fabaceae) and cattle in the Monte desert: seeds, seedlings and saplings on cattle-use site classes. Revista Chilena de Historia Natural 84, 289-299.

Campos, C.M. and Velez, S. (2015) Almacenadores y frugívoros oportunistas: el papel de los mamíferos en la dispersión del algarrobo (Prosopis flexuosa DC) en el desierto del Monte, Argentina. Revista Ecosistemas 24, 28-34.

Campos, C.M., Campos, V.E., Miguel, F. and Cona, M.I. (2016) Management of protected areas and its effect on an ecosystem function: removal of Prosopis flexuosa seeds by mammals in Argentinian drylands. PLOS ONE 11, e0162551. doi: 10.1371/journal.pone.0162551
Campos, C.M., Campos, V.E., Giannoni, S.M., Rodríguez, D., Albanese, S. and Cona, M.I. (2017) Role of small rodents in the seed dispersal process: Microcavia australis consuming Prosopis flexuosa fruits. Austral Ecology 42, 113119. doi: $10.1111 /$ aec.12406

Chillo, V. and Ojeda, R.A. (2012) Mammal functional diversity loss under human-induced disturbances in arid lands. Journal of Arid Environments 87, 95-102.

Connel, 1.J.H. (1971) On the roles of natural enemies in preventing competitive exclusion in some marine animals and in rain forest trees. In den Boer, P.J. and Gradwell, G.R. (eds), Dynamics of Populations: Proceedings of the Advanced Study Institute on Dynamics of Numbers in Populations, pp. 298-312. Netherlands: Centre for Agricultural Publication and Documentation Wageningen.

Corbalán, V. (2006) Microhabitat selection by murid rodents in the Monte desert of Argentina. Journal of Arid Environments 65, 102-110.

Corbalán, V. and Ojeda, R.A. (2004) Spatial and temporal organization of small mammal communities in the Monte desert, Argentina. Mammalia 68, 5-14.

Dalmasso, A.D. and Anconetani, J. (1993) Productividad de frutos de Prosopis flexuosa (Leguminosae), algarrobo dulce, en Bermejo, San Juan. Multequina 2, 173-181.

Estrella, H., Boshoven, J. and Tognelli, M. (2001) Características del clima regional y de la Reserva de Ñacuñán. In Claver, S. and Roig-Juñent, S. (eds), El desierto del Monte: La Reserva de Biosfera de Ñacuñán, Mendoza, Argentina, pp. 25-33. Córdoba, Argentina, Editorial Triunfar.

Flowerdew, J.R. and Ellwood, S.A. (2001) Impacts of woodland deer on small mammal ecology. Forestry 74, 277-287.

Forget, P.-M., Ranking-De Merona, J.M. and Julliot, C. (2001) The effects of forest type, harvesting and stand refinement on early seedling recruitment in a tropical rain forest. Journal of Tropical Ecology 17, 593-609.

Forget, P.-M., Hammond, D., Milleron, T. and Thomas, R. (2002) Seasonality of fruiting and food hoarding by rodents in Neotropical forests: consequences for seed dispersal and seedling recruitment. In Levey, D.J., Silva, W. R. and Galetti, M. (eds), Seed Dispersal and Frugivory: Ecology, Evolution and Conservation, pp. 241-253. Wallingford, UK: CABI Publishing.

Forget, P.-M. and Cuijpers, L. (2008) Survival and scatterhoarding of frugivores- dispersed seeds as a function of forest disturbance. Biotropica 40, 380-385.

Foster, C.N., Barton, P.S, Lindenmayer, D.B. and Toit, J. (2014) Effects of large native herbivores on other animals. Journal of Applied Ecology 51, 929-938.

Giannoni, S.M., Dacar, M., Taraborelli, P. and Borghi, C.E. (2001) Seed hoarding by rodents of the Monte Desert, Argentina. Austral Ecology 26, 259-263.

Giannoni, S.M., Campos, V.E., Andino, N., Ramos-Castilla, M., Orofino, A., Borghi, C.E., de los Ríos, C. and Campos, C.M. (2013) Hoarding patterns of sigmodontine rodent species in the Central Monte Desert (Argentina). Austral Ecology 38, 485-492.

Grünewald, C., Breitbach, N. and Böhning-Gaese, K. (2010) Tree visitation and seed dispersal of wild cherries by terrestrial mammals along a human land-use gradient. Basic and Applied Ecology 11, 532-541.

Guevara, J.C., Grünwaldt, E.G., Estevez, O.R., Bisigato, A.J., Blanco, L.J., Biurrun, F.N., Ferrando, C.A., Chirino, C.C., Morici, E., Fernández, B., Allegretti, L.I. and Passera, C. B. (2009) Range and livestock production in the Monte 
Desert, Argentina. Journal of Arid Environments 73, 228-237.

Howe, H.F. and Smallwood, J. (1982) Ecology of seed dispersal. Annual Review of Ecology, Evolution and Systematic 13, 201-228.

Iob, G. and Vieira, E.M. (2008) Seed predation of Araucaria angustifolia (Araucariaceae) in the Brazilian Araucaria Forest: influence of deposition site and comparative role of small and 'large' mammals. Plant Ecology 198, 185-196.

Janzen, D.H. (1971) Seed predation by animals. Annual Review of Ecology, Evolution and Systematic 2, 465-492.

Janzen, D.H. (1974) The deflowering of Central America. Natural History 83, 48-53.

Janzen, D.H. (1983) Insects. In Janzen, D.H. (ed), Costa Rican Natural History, pp. 619-645. Chicago: University of Chicago Press.

Jiménez, J.E., Lucherini, M. and Novaro, A.J. (2008) Pseudalopex griseus, in The IUCN Red List of Threatened Species 2008. Available at: http://dx.doi.org/10.2305/ IUCN.UK.2008.RLTS.T6927A12815779.en (last accessed 14 March 2017).

Jones, A. (2000) Effects of cattle grazing on North American arid ecosystems: a quantitative review. Western North American Naturalist 60, 155-164.

Jordano, P. (2000) Fruits and frugivory. In Fenner, M. (ed), Seeds: The Ecology of Regeneration in Plant Communities, 2nd edition, pp. 125-166. Wallingford, UK: CABI Publishing.

Jordano, P., Forget, P.-M., Lambert, J.E., Böhning-Gaese, K., Traveset, A. and Wright, S.J. (2011) Frugivores and seed dispersal: mechanisms and consequences for biodiversity of a key ecological interaction. Biological Letters 7, 321-323.

Kelly, D. and Sork, V. (2002). Mast seeding in perennial plants: why, how, where? Annual Review of Ecology and Systematics 33, 427-447.

Kelt, D.A., Meserve, P.L. and Gutiérrez, J.R. (2004) Seed removal by small mammals, birds and ants in semi-arid Chile, and comparison with other systems. Journal of Biogeography 31, 931-942.

Kingsolver, J.M., Johnson, C.D., Swier, S.R. and Teran, A. (1977) Prosopis fruits as a resource for invertebrates. In Simpson, B.B. (ed), Mesquite: Its Biology in Two Desert Scrub Ecosystems, pp. 108-122. Pennsylvania: Dowden, Hutchinson and Ross.

Ladio, A.H. and Lozada, M. (2009) Human ecology ethnobotany and traditional practices in a rural population of the Monte region, Argentina: resilience and ecological knowledge. Journal of Arid Environments 73, 222-227.

Linzey, A. and Washok, K.A. (2000) Seed removal by ants, birds and rodents in a woodland savanna habitat in Zimbabwe. African Zoology 35, 295-299.

Longland, W.S., Jenkins, S.H., Vander Wall, S.B., Veech, J.A. and Pyare, S. (2001) Seedling recruitment in Oryzopsis hymenoides: are desert granivores mutualists or predators? Ecology 82, 3131-3148.

López de Casenave, J., Cueto, V.R. and Marone, L. (1998) Granivory in the Monte desert, Argentina: is it less intense than in other arid zones of the world? Global Ecology and Biogeography Letters 7, 197-204.

Marone, L., López de Casenave, J. and Cueto, V.R. (2000) Granivory in southern South American deserts: conceptual issues and current evidence. BioScience 50, 123-132.

McCullagh, P. and Nelder, J.A. (1989) Generalized Linear Models. Monographs on Statistics and Applied Probability. London: Chapman and Hall.
McCulloch, C.E. and Searle, S.R. (2001) Generalized Linear and Mixed Models. Hoboken, New Jersey: John Wiley and Sons, Inc.

Millennium Ecosystem Assessment (2005). Synthesis Reports. www.millenniumassessment.org.

Nathan, R. (2006) Long-distance dispersal of plants. Science 313, 786-788.

Ojeda, R.A. (1989) Small mammal responses to fire in the Monte desert, Argentina. Journal of Mammalogy 70, 416-420.

Periago, M.E., Chillo, V. and Ojeda, R.A. (2014) Loss of mammalian species from the South American Gran Chaco: empty savanna syndrome? Mammalogical Review 45, 41-53.

R Development Core Team (2016) R: A Language and Environment for Statistical Computing. Vienna: $\mathrm{R}$ Foundation for Statistical Computing. Available at: http://www.R-project.org/ (last accessed 14 March 2017).

Reynolds, J.F., Stafford Smith, D.M., Lambin, E.F., Turner, B.L., Mortimore, M., Batterbury, S.P.J., Downing, T.E., Dowlatabadi, H., Fernández, R.J., Herrick, J.E., Huber-Sannwald, E., Jiang, H., Leemans, R., Lynam, T., Maestre, F.T., Ayarza, M. and Walker, B. (2007) Global desertification: building a science for dryland development. Science 316, 847-851.

Rodríguez, D. (2009) Modeling habitat use of the threatened and endemic mara (Dolichotis patagonum, Rodentia, Caviidae) in agricultural landscapes of Monte Desert. Journal of Arid Environments 73, 444-448.

Roig, F.A. (1971) Flora y vegetación de la Reserva Forestal de Nacuñán. Deserta 1, 25-232.

Roig, F.A., Roig-Juñent, S. and Corbalán, V. (2009) Biogeography of the Monte Desert. Journal of Arid Environments 73, 164-172.

Rojas, J.F., Prieto, M. del R., Álvarez, J.A. and Cesca, E. (2009) Procesos socioeconómicos y territoriales en el uso de los recursos forestales en Mendoza desde fines de siglo XIX hasta mediados del XX. Proyección 7, 1-33.

Sánchez-Cordero, V. and Martínez-Gallardo, R. (1998) Post dispersal fruit and seed removal by forest-dwelling rodents in a lowland rain forest in Mexico. Journal of Tropical Ecology 14, 139-151.

Schupp, E.W., Jordano, P. and Gómez, J.M. (2010) Seed dispersal effectiveness revisited: a conceptual review. New Phytologist 188, 333-353.

Tabeni, S. and Ojeda, R.A. (2003) Assessing mammal responses to perturbations in temperate aridlands of Argentina. Journal of Arid Environments 55, 715-726.

Tabeni, S. and Ojeda, R.A. (2005) Ecology of the Monte Desert small mammals in disturbed and undisturbed habitats. Journal of Arid Environments 63, 244-255.

Tabeni, S., Mastrantonio, L. and Ojeda, R.A. (2007) Linking small desert mammal distribution to habitat structure in a protected and grazed landscape of the Monte, Argentina. Acta Oecologica 31, 259-269.

Tabeni, S., Spirito, F. and Ojeda, R.A. (2013) Conservation of small and medium-sized mammals following native woodland regrowth: a case study in a long-term UNESCO Biosphere Reserve, Argentina. Journal of Arid Environments 88, 250-253.

Tognelli, M., Campos, C.M., Ojeda, R.A. and Roig, V. (1995) Is Microcavia australis (Rodentia: Caviidae) associated with a particular plant structure in the Monte desert of Argentina? Mammalia 59, 327-333.

Vander Wall, S.B. (1990) Food Hoarding in Animals. Chicago: University of Chicago Press. 
Vander Wall, S.B. (2002) Masting in animal-dispersed pine facilitates seed dispersal. Ecology 83, 3508-3516.

Vander Wall, S.B. and Beck, M.J. (2012) A comparison of frugivory and scatter-hoarding seed-dispersal syndromes. The Botanical Review 78, 10-31.

Villagra, P.E., Marone, L. and Cony, M. (2002) Mechanisms affecting the fate of Prosopis flexuosa (Fabaceae, Mimosoideae) seed during early secondary dispersal in the Monte Desert, Argentina. Austral Ecology 27, 416-421.
Warrag, M.O.A. (1994) Autotoxicity of mesquite (Prosopis juliflora) pericarps on seed germination and seedling growth. Journal of Arid Environments 27, 79-84.

Zeileis, A., Kleiber, C. and Jackman, S. (2008) Regression models for count data in R. Journal of Statistical Software 27, 1-25.

Zuur, A.F., Ieno, E.N., Walker, N.J., Saveliev, A.A. and Smith, G.A. (2009) Mixed Effects Models and Extensions in Ecology with R. New York: Springer. 